\title{
Native pig (Moo Lat) breeds in Lao PDR (Short Communication)
}

Soukanh Keonouchanh', Istvan Egerszegi², Jozsef Ratky'2, Bouahom Bounthong', Noboru Manabe ${ }^{3}$ and Klaus-Peter Brüssow ${ }^{4}$

'Livestock Research Center, National of Agriculture and Forestry Research Institute (NAFRI) Ministry of Agriculture and Forestry (MAF), Vientiane, Lao PDR, ${ }^{2}$ Research Institute for Animal Breeding and Nutrition (ATK), Herceghalom, Hungary, ${ }^{3}$ Animal Resource Science Center, Graduate School of Agricultural and Life Sciences, The University of Tokyo, Japan, ${ }^{4}$ Department of Reproductive Biology, Leibniz Institute for Farm Animal Biology (FBN), Dummerstorf, Germany

\begin{abstract}
Pig production continues to be an important livelihood activity in the Lao People's Democratic Republic (Lao PDR) which base on traditional methods. However, it is increasingly affected by social and market pressures. More than $80 \%$ of pig herds are native breeds and belong to smallholders with combined keeping systems. Based on a national field survey, the native pigs have been characterized and classified in four phenotypes. The native pig types and their local distribution are described. Most of them have short ears, black colour and potbelly. Their production performance, i.e. growth rates and daily weight gain is lower and the carcass fat considerably higher than that of exotic (i.e. in Lao terms »modern, intensive«) breeds. However, they require lower inputs and have excellent adaptation traits.
\end{abstract}

Keywords: Lao native pigs (Moo Lat), reproductive performance, smallholder system

\section{Zusammenfassung}

\section{Einheimische (Moo Lat) Schweinerassen in der Demokratischen Volksrepublik Laos (Kurzmitteilung)}

Die Schweineproduktion in der Demokratischen Volksrepublik Laos, die vorwiegend auf traditionellen Produktionsmethoden basiert, ist ein wichtiges Mittel zum Lebensunterhalt der Menschen. Sie steht zunehmend unter dem Druck der Nachfrage und des Marktes. Mehr als $80 \%$ der Schweine sind einheimische Rassen und werden von Kleinhaltern in kombinierten Produktionssystemen gehalten. Auf der Basis einer national durchgeführten Erfassung wurden die einheimischen Schweine charakterisiert und in vier Phänotypen eingeteilt. Die Typen und ihre lokale Verbreitung werden beschrieben. Die meisten von ihnen haben kurze Ohren, eine schwarze Hautfarbe und einen Dickbauch. Ihre Produktionsleistungen, wie z.B. Wachstumsraten und Tageszunahmen, sind geringer und der Fettanteil im Schlachtkörper ist wesentlich höher als bei exotischen (d. h. in Laos »moderne, intensive«) Rassen. Sie brauchen jedoch weniger zum Unterhalt und sind hervorragend adaptiert.

Schlüsselwörter: Moo Lat-Schweinerassen, dickbäuchige Fettrassen, Fortpflanzungsleistung, Kleinhaltersystem 


\section{Introduction}

About $85 \%$ of the working population of the Lao People's Democratic Republic (PDR) is engaged in agriculture. The agricultural sector contributes to about $52 \%$ of the gross domestic product (GDP) including $18 \%$ by the livestock and fisheries sub-sector (MAF 2005). In 2007, the livestock population consisted of 1.15 million buffalo, 1.5 million cattle, 21.9 million poultry, 280000 goats and 2.5 million pigs (with about $20 \%$ of them being exotics, i.e. in Lao terms 'modern, intensive' breeds). The smallholder production system dominates in Lao PDR and is characterized by low inputs and low outputs. The traditional livestock management practice is based on free-range grazing of harvested or fallow lands. Breeding is generally uncontrolled with nearly negligible attempts for genetic improvement.

Pig production is the most significant part of smallholder livestock management in Laos and becomes increasingly important for food supply. The social demand for pork is rapidly growing and the small scale pig production cannot satisfy it. Consequently, the import of prefattened pigs for slaughter from neighbouring countries is increasing. In 2007, pork was the second most consumed meat with estimated $11.55 \mathrm{~kg}$ per capita (Department of Livestock and Fisheries 2008). The density of pig population is highest in the northern and southern mountainous regions. Differences exist between the ethnic groups regarding household keeping of pigs: $73 \%$ of the Hmong people, $84 \%$ of Khmu and $38 \%$ of Lao ethnic groups rear pigs (Agricultural Census 2000). It must be considered here that indigenous pig production is both a source of income and livelihood to reduce poverty and of gene pool conservation.

So far, no nation-wide survey of indigenous pig breeds exists. The aim of the study was to register, and to identify and to describe the current indigenous pig population in the Lao PDR. Furthermore, information should be given on growth performance and carcass composition in Moo Lat pigs after feeding different levels of a commercial diet.

\section{Materials and methods}

Nation-wide indigenous pig survey was performed from 1996 to 2004. Altogether 35 districts were selected for the survey and ten villages were analysed for each district. In each village, seven households with more than three adult pigs per ownership were interviewed. The main tools for data collection were interviews based on questionnaire form and visual evaluation. The interview covered many areas of interest connected to pig production, i.e. management, breeds, food and feeding system, and reproduction performance. The provincial livestock officers who were supervising the survey at the provinces sorted out the data which were afterwards compiled on national level by using Microsoft Access (Microsoft Corporation, Redmond, WA, USA) software. Criteria taken into consideration to identify the different types of indigenous pigs were body length, circumference of the girth, height, colour of the skin and the direction of the ears.

Furthermore, growth performance and carcass composition were analysed first in Moo Lat pigs after feeding different levels of a commercial diet. Altogether 30 healthy castrated males weighing $10-12 \mathrm{~kg}$ were included into the trial. Two weeks before the experimental phase animals were treated against internal parasites, vaccinated and their growth rate were recorded feeding ad libitum a commercial diet. Pigs were randomly allocated to five feeding 
groups ( $n=6$ per group). Animals were kept in individual pens and had free access to fresh water. The control group was fed ad libitum and the other four treatment groups received the same diet, but the level was restricted for $10,20,30$ or $40 \%$. During the experimental period animals were weighted weekly and the feed intake was recorded. Pigs were fed to a final weight of $60 \mathrm{~kg}$ and then slaughtered. Carcass weight, lean meat and fat content and thickness of back fat were measured at slaughter, and daily weight gain, days to final weight of $60 \mathrm{~kg}$ and feed consumption were calculated. All data were analysed by ANOVA.

\section{Results and discussion}

Based on the aforementioned criteria, pigs were classified into four types. The phenotype, the reproductive performance and dissemination of the four types are presented following.

\section{Type 1: Local names - Moo Chid, Moo Markadon, Moo Boua}

The first type is scattered countrywide. The pig is of relatively small size compared to other types existing in the country. Its body length, circumference of the girth and the height is 75$92 \mathrm{~cm}, 72-85 \mathrm{~cm}$ and $46-54 \mathrm{~cm}$, respectively. The ears are small, short and directed forward. The coat colour is mainly black and legs are white.

Gilts show first oestrus at the age of about 6 months (between 182-197 days) and with body weight of $21-31 \mathrm{~kg}$. The weight of mature sows is about $42-48 \mathrm{~kg}$. The age at first farrowing is approx. 360 days. There are 1.5 litters per year with 7-8 piglets per litter. Normal weaning age is three months with an average weaning weight of the piglets of $7.8 \mathrm{~kg}$.

Mature males have lower body weight than females, i.e. the average body weight is $20.5 \mathrm{~kg}$ at the age of 170-200 days, and the maximum body weight of boars is between $18-30 \mathrm{~kg}$.

\section{Type 2: Local names - Moo Lat}

The second type is mostly present in upland areas (Luangprabang, Oudomxay, Xaysomboun), but also in some lowland territories (Saravane and Savannakhet provinces). This breed is quite bigger than the first type. Body length is $85-100 \mathrm{~cm}$; the girth and height are $84-102 \mathrm{~cm}$ and $51-70 \mathrm{~cm}$, respectively. The ears are short and directed forward and the face is strait. Legs and the front of the face are white.

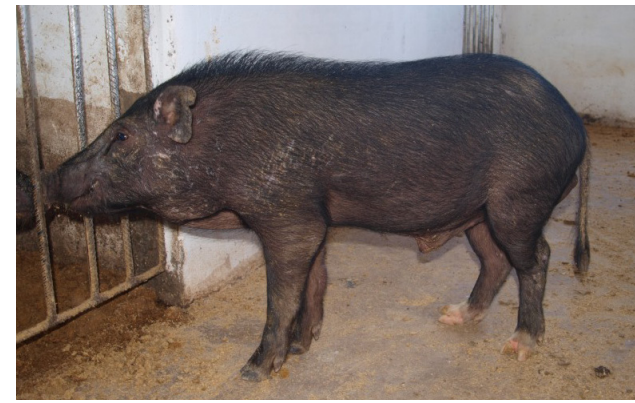

Figure 1

Type 1: Local names - Moo Chid, Moo Markadon, Moo Boua

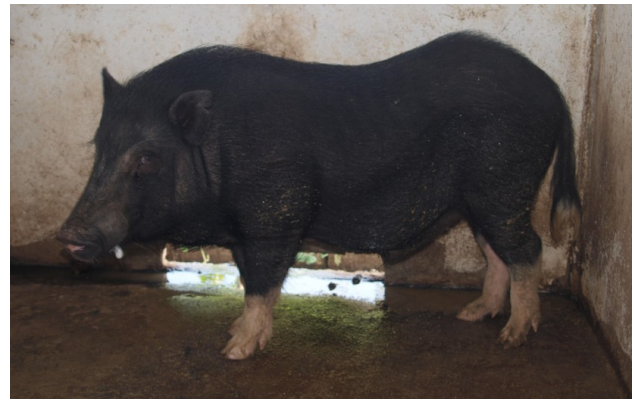

Figure 2

Type 2: Local names - Moo Lat 
The age of the first oestrus is between 189-586 days with $39 \mathrm{~kg}$ of body weight. These varying data depend on typical extensive keeping systems, where management is nearly negligibly. The weight of mature sows is about $47-61 \mathrm{~kg}$, and the youngest age of first farrowing is around 360 days. Depending on management systems, sows have 1.5-1.8 litters per year and 7-8 piglets per litter. Normal weaning period is $60-90$ days with an average of $9.5 \mathrm{~kg}$ of piglet's weaning weight.

Mature males of this type have also lower body weight $(25 \mathrm{~kg})$ than females and maximum body weight of boars can reach $30-50 \mathrm{~kg}$.

\section{Type 3: Local names - Moo Nonghad or Moo Hmong}

This type is specifically found in the Nonghad district, Xienkhouang province. It is quite big with body length of $100-105 \mathrm{~cm}$, girth circumference of $115-130 \mathrm{~cm}$ and height of $55-76 \mathrm{~cm}$. The body is mostly black and in the abdominal region rose coloured. It has a short and bent face, and the medium sized ears are directed forward.

The age at the first oestrus is between $150-180$ days with $30-40 \mathrm{~kg}$ of body weight. The weight of mature sows is between 65 and $85 \mathrm{~kg}$. The age at first farrowing is 10-11 months. There are 1.5-1.8 litters per year with 7-10 piglets per litter. Normal weaning age of the piglets is $2-3$ months and the weaning weight is $8 \mathrm{~kg}$ on average.

The maximum body weight of boars is between $60-80 \mathrm{~kg}$.

\section{Type 4: Local name - Moo Deng or Moo Berk}

The fourth type is easy to identify due to its phenotype. It has brown colour and is apparently larger than any other pig breed existing in Lao PDR. This pig is a well-adopted and stabilized cross-bred one (Berkshirexlocal pig). It is kept only in the southern part of Laos, particularly in Mounlapamok and Khong districts, Champasack province. Body length, circumference of the girth and the height are $88-120 \mathrm{~cm}, 84-116 \mathrm{~cm}$ and $60-70 \mathrm{~cm}$, respectively. It has a short and bent face, and large sized hanging ears.

The weight of mature sows is around $65-90 \mathrm{~kg}$, and the first farrowing age is between 330-360 days. They have 1.5-1.8 litters per year with 7-10 piglets per litter. Piglets are normally weaned at the age of 2-3 months and a weight of $8.5 \mathrm{~kg}$.

The maximum body weight of boars is similar to sows.

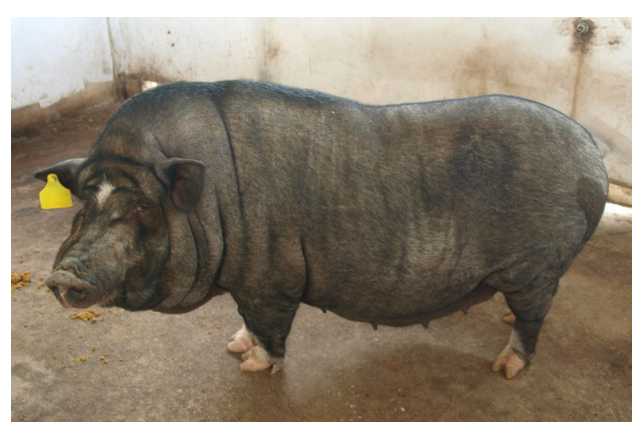

Figure 3

Type 3: Local names - Moo Nonghad or Moo Hmong

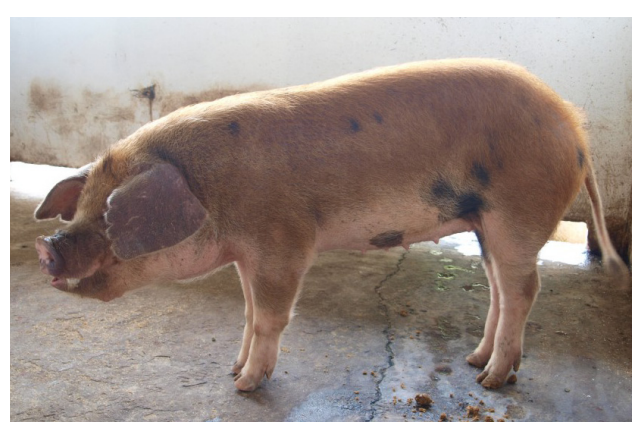

Figure 4

Type 4: Local name - Moo Deng or Moo Berk 
It should be mentioned that the description of the four types is still a preliminary classification which base only on phenotypical differences. More research activities with advanced techniques like DNA analysis are required to characterize the different breeds finally. Oosterwijk et al. (2003) described three types of endogenous pig breeds; however, others mentioned the previously described four classes (FAO 2007, Wilson 2007).

\section{Keeping systems}

Based on the survey data, there are several modes how the farmers manage and feed their pigs. One is the extensive system of free range scavenge all the time and supplementing some food in the morning and evening. Semi-extensive systems comprise both free range scavenge during the day and supplementary food supply and indoor keeping in simple pens during the night time. Semi-intensive keeping systems include simple housing and food supply, whereas in intensive systems pigs are kept in permanent pens and feeding.

However, there are several combinations of these basic management systems with relation to the traditions of ethnic groups.

\section{Growth performances and carcass compositions}

The average daily gain (ADG) of Moo Lat pigs which are kept extensively in the Lao PDR uplands does not exceed $100 \mathrm{~g}$ (unpublished field survey data). Usually, the pigs are fed diets which base mainly on rice bran, maize and cassava roots with some additional green plant material. However, they are not available the whole year. In extensive systems where farmers supplemented the feed with Stylosanthes guianensis (forage legume) ADG could be increased from 107 to $207 \mathrm{~g} /$ day (Phengsavanh \& Stür 2006). If Moo Lat pigs were fed with a nutrient rich diet, ADG grew up to more than $500 \mathrm{~g}$ per day (Table 1) with influence on fat content and body composition (Table 2).

Table 1

Growth performance of indigenous Moo Lat pigs fed restricted levels of commercial diets

\begin{tabular}{lcccccc}
\hline Parameter & \multicolumn{5}{c}{ Restriction of feeding level } \\
& $0 \%$ & $10 \%$ & $20 \%$ & $30 \%$ & $40 \%$ & LSD \\
\hline Number of animals, $\mathrm{n}$ & 6 & 6 & 6 & 6 & 6 & \\
Initial weight, $\mathrm{kg}$ & 21.3 & 20.8 & 19.7 & 18.7 & 21.2 & 3.14 \\
Final weight, $\mathrm{kg}$ & 61.7 & 60.8 & 61.3 & 61.2 & 61.9 & 1.38 \\
Total weight gain, $\mathrm{kg}$ & 41.4 & 40.5 & 41.0 & 40.8 & 41.6 & 1.43 \\
Days to final weight & $77^{\mathrm{a}}$ & $76^{\mathrm{a}}$ & $80^{\mathrm{a}}$ & $94^{\mathrm{b}}$ & $122^{\mathrm{c}}$ & 8.70 \\
Average daily gain, $\mathrm{g}$ & $558^{\mathrm{a}}$ & $542^{\mathrm{a}}$ & $523^{\mathrm{b}}$ & $446^{\mathrm{b}}$ & $346^{\mathrm{c}}$ & 57.1 \\
Feed consumption rate, $\mathrm{kg}$ & $3.61^{\mathrm{a}}$ & $3.39^{\mathrm{a}, \mathrm{b}}$ & $3.23^{\mathrm{b}}$ & $3.21^{\mathrm{b}}$ & $3.44^{\mathrm{a}, \mathrm{b}}$ & 0.27 \\
\hline
\end{tabular}

$\mathrm{a}, \mathrm{b}, \mathrm{c} P<0.05$

The growth rate of pigs fed restrictedly or ad libitum with a commercial diet was higher than in other studies. Growth rates ranging between 113 and $232 \mathrm{~g} /$ day were achieved when local pigs in Thailand were fed vegetable, stylo leaves and concentrates (Ratchadawan et al. 2006). Xaypha et al. (2007) reported 155 to $193 \mathrm{~g} /$ day when Moo Lat pigs were fed cassava leaf silage. Supplementing feed with stylo leaves, Keoboualapheth et al. (2003) found that the growth rate of native pigs was 154 to $320 \mathrm{~g} /$ day. 
Table 2

Carcass composition of indigenous Moo Lat pigs fed restricted levels of commercial diets

\begin{tabular}{lcccccc}
\hline Parameter & \multicolumn{5}{c}{ Restriction of feeding level } \\
& $0 \%$ & $10 \%$ & $20 \%$ & $30 \%$ & $40 \%$ & LSD \\
\hline Number of animals & 6 & 6 & 6 & 6 & 6 & \\
Pre-slaughter weight, kg & 62.0 & 61.7 & 61.1 & 62.0 & 62.0 & 1.45 \\
Back fat at P2, cm & 3.4 & 3.5 & 3.3 & 3.4 & 3.1 & 5.01 \\
Carcass weight, kg & 42.7 & 42.7 & 41.8 & 42.1 & 42.3 & 1.72 \\
Total fat, kg & $25.3^{\mathrm{a}}$ & $24.2^{\mathrm{ab}}$ & $23.5^{\mathrm{ab}}$ & $22.3^{\mathrm{bc}}$ & $20.3^{\mathrm{c}}$ & 2.59 \\
Fat, \% & $59^{\mathrm{a}}$ & $57^{\mathrm{a}}$ & $56^{\mathrm{a}}$ & $53^{\mathrm{ab}}$ & $48^{\mathrm{c}}$ & 6.2 \\
Total lean meat, kg & $14.8^{\mathrm{a}}$ & $14.5^{\mathrm{a}}$ & $15.2^{\mathrm{a}}$ & $15.0^{\mathrm{a}}$ & $16.9^{\mathrm{b}}$ & 1.16 \\
Lean meat, \% & $35^{\mathrm{a}}$ & $34^{\mathrm{a}}$ & $36^{\mathrm{b}}$ & $36^{\mathrm{b}}$ & $40^{\mathrm{c}}$ & 2.6 \\
\hline
\end{tabular}

$\mathrm{a}, \mathrm{b}, \mathrm{c} p<0.05$

Due to longer $(P<0.05)$ period to gain the final slaughter weight of $60 \mathrm{~kg}$, pigs of the $40 \%$ feed restriction group revealed a significant lower ADG.

Pigs $(n=30)$, which were fed restrictedly, were slaughtered when they attained body weight of $60 \mathrm{~kg}$. The carcass weight of about $42 \mathrm{~kg}$ was similar in all treatment groups (Table 2). Non-restricted pigs ( $0 \%)$ gained the highest fat content which was significant $(P<0.05)$ compared to groups of $30-40 \%$ restriction level. The amount of lean meat (16.9 $\mathrm{kg}$ or $40 \%)$ was higher $(P<0.05)$ in animals fed a $40 \%$ feed restriction.

Additionally, the analysis if the questionnaires revealed several constrains of pig production at the village level. The main constraints are (1) the absence of breeding management due to the free ranging and uncontrolled mating system; (2) the lack of suitable management with regard to high piglet mortality; (3) the insufficient quality of feed which is responsible of poor growth rates; and (4) epidemic diseases, e.g. classical swine fever.

In conclusion, the national pig survey in the Lao PDR indicates that the initiated phenotypical classification of native pigs is not completed and requires additional genetic estimations. The potential growth performance of native Lao Moo Lat pigs can be considerably increased when they are fed with high quality diets which satisfy the energy and protein requirements. However, an excess of fat accumulation should be avoided feeding nutrient rich diets. Furthermore, farmers need to get knowledge and training of production (nutrition) strategies to ensure optimal performance. The awareness of farmers should be improved to maintain and properly use the genetic resources of native pigs for more efficient and sustainable food production and long-term food security.

Extensive production system should be replaced by semi-intensive or intensive system using an appropriate technology to increase quantity, quality and safety of products.

\section{References}

Agricultural Census (2000) Lao Agriculture Census 1998-1999. Steering Committee for the Agricultural Census, Agricultural Census Office, Vientiane Lao PDR

Department of Livestock and Fisheries (2008) Annual meeting 20-21 November 2008, Vientiane Lao PDR FAO (2007) The State of the World's Animal Genetic Resources for Food and Agriculture, ed. by B Rischkowsky, D Pilling. Rome, Italy 
Keoboualapheth C, Mikled C (2003) Growth performance of indigenous pigs fed with Stylosanthes guianensis CIAT 184 as replacement for rice bran. Livest Res Rural Dev 15, 9

MAF=Ministry of Agriculture and Forestry (2005) The Strategic Plan for Agricultural Sector 2005-2010, Wellington, New Zealand

Oosterwijk G, van Aken D, Vongthilath S (2003) A Manual on Improved Rural Pig Production. Department of Livestock and Fisheries, Ministry of Agriculture and Forestry, Vientiane, Lao PDR

Phengsavanh P, Stür W (2006) The use and potential of supplementing village pigs with Stylosanthes guianensis in Lao PDR. Workshop-seminar »Forages for Pigs and Rabbits«. 22-24 August 2006, MEKARNCelAgrid, Phnom Penh, Cambodia

Ratchadawan P, Virapon P, Nikom V, Satit M (2006) Utilization of Tapra Stylo for native swine on highland in northern Thailand. Proc. 44th Kasetsart University Annual Conference, 30.01-2.2., Kasetsart, Thailand

Wilson RT (2007) Status and prospects for livestock production in the Lao People's Democratic Republic. Trop Anim Health Prod 39, 443-452

Xaypha S, Keonouchanh S, Phimphachanhvongsot V, Reinhard H, Tin Maun A (2007) The use of cassava silage in diets for growing local pigs in Laos. Lao J Agric Forest 14, 1-10

Received 23 March 2011, accepted 31 August 2011.

Corresponding author:

Klaus-Peter Brüssow

email: bruessow@fbn-dummerstorf.de

Department of Reproductive Biology, Leibniz Institute for Farm Animal Biology (FBN), Wilhelm-Stahl-Allee 2, 18196 Dummerstorf, Germany 